\title{
First report of gray mold on Ocimum basilicum (sweet basil) caused by Botrytis cinerea in Japan
}

\author{
Jamjan Meeboon ${ }^{1} \cdot$ Makoto Shinohara $^{1}$ \\ Received: 18 March 2020 / Accepted: 14 July 2020 / Published online: 21 July 2020 \\ (C) Società Italiana di Patologia Vegetale (S.I.Pa.V.) 2020
}

Keywords ITS $\cdot$ Nuclear protein-coding genes $\cdot$ Pathogenicity

Sweet basil grows as a spice in the food industry, medicinal, and aromatic plant. In September 2019, a disease was observed in ninety infected sweet basils grown in greenhouse of Mie. Symptoms included extensive growth of mycelia with graybrownish conidia on leaves and stems of the plants. Monoconidial isolates were obtained by plating conidial suspensions on potato dextrose agar and selecting single colonies. Incubation of isolates at $25^{\circ} \mathrm{C}$ for 21 days produced blackish, spherical to irregular microsclerotia and measured 1-4×1$3 \mathrm{~mm}$. Conidia were one-celled, ellipsoid to ovoid, colorless to pale-brown, and measured $6-15 \times 5-10 \mu \mathrm{m}$. To confirm identification, the internal transcribed spacer region of rDNA, three nuclear protein-coding genes, glyceraldehyde-3phosphate dehydrogenase, heat-shock protein 60 and RNA polymerase subunit II (amplified by using ITS1/ITS4, G3PDHf/ G3PDHr, HSP60f/HSP60r and RPB2f/RPB2r primers) of a representative isolate were sequenced (Staats et al. 2005). All the sequences generated were deposited to the NCBI database (accession Nos. MT138533, MT193023-MT193025). To ensure the identity of the $B$. cinerea, three nuclear protein-coding gene regions were combined (Aktaruzzaman et al. 2015), aligned and subsequently used to construct a phylogenetic tree based on a maximum parsimony analysis. The phylogenetic tree resulted in a supported placement of the $B$. cinerea strains obtained in this study confirming its identification as $B$. cinerea. To confirm pathogenicity, 20-days-old plants were sprayed with the suspension of conidia $\left(10^{7}\right.$ conidia/ml). Lesions developed on leaves and stems of inoculated plants 7 days after inoculation, whereas control plants remained healthy. Reisolations were successfully made from the inoculated leaves,

Jamjan Meeboon

jamjanm@yahoo.com; mibunj714@affrc.go.jp

1 Institute of Vegetable and Floriculture Science, National Agriculture and Food Research Organization, Mie Tsu 514-2392, Japan fulfilling the Koch's postulates. Association of sweet basil with B. cinerea has been reported in Greece, Hungary, Italy, Chile, Turkey and Poland (Farr and Rossman 2019) but not in Japan. This is the first report of gray mold on sweet basil in Japan.

Acknowledgements This work was financially supported by the Japan Science and Technology Agency (JST): The Advanced Low Carbon Technology Research and Development Program (ALCA) to Makoto Shinohara, no. JPMJAL1606.

\section{Compliance with ethical Standards}

Conflict of interest The authors declare that they have no conflict of interest.

Ethical statements This article does not contain any studies with human participants or animals performed by any of the authors.

\section{References}

Aktaruzzaman MD, Kim JY, Afroz T, Kim BS (2015) First report of gray mold disease of sweet basil (Ocimum basilicum) caused by Botrytis cinerea in Korea. Kor J Mycol 43:277-280

Farr DF, Rossman AY (2019) Fungal databases, syst. Mycol. Microbiol. Lab., Online publication. ARS, USDA. Retrieved March 3, 2020

Staats M, van Baarlen P, van Kan JA (2005) Molecular phylogeny of the plant pathogenic genus Botrytis and the evolution of host specificity. Mol Biol Evol 22:333-346

Publisher's note Springer Nature remains neutral with regard to jurisdictional claims in published maps and institutional affiliations. 